\title{
IdeAs
}

Idées d'Amériques

1| 2011

Intégrations dans les Amériques

\section{NAFTA's Developmental Impact on Mexico: Assessment and prospects}

Impact socio-économique de l'ALENA au Mexique: Bilan et perspectives

Impacto socioeconómico del TLCAN sobre México: balance y perspectivas

\section{Jean-Baptiste Velut}

\section{OpenEdition}

\section{Journals}

Édition électronique

URL : https://journals.openedition.org/ideas/71

DOI : 10.4000/ideas.71

ISSN : $1950-5701$

Éditeur

Institut des Amériques

Référence électronique

Jean-Baptiste Velut, "NAFTA's Developmental Impact on Mexico: Assessment and prospects », IdeAs [En ligne], 1 | 2011, mis en ligne le 31 août 2011, consulté le 18 octobre 2022. URL : http:// journals.openedition.org/ideas/71 ; DOI : https://doi.org/10.4000/ideas.71

Ce document a été généré automatiquement le 18 octobre 2022.

\section{(†) $९$}

Creative Commons - Attribution - Pas d'Utilisation Commerciale - Pas de Modification 4.0 International - CC BY-NC-ND 4.0

https://creativecommons.org/licenses/by-nc-nd/4.0/ 


\title{
NAFTA's Developmental Impact on Mexico: Assessment and prospects
}

\author{
Impact socio-économique de l'ALENA au Mexique: Bilan et perspectives \\ Impacto socioeconómico del TLCAN sobre México: balance y perspectivas
}

Jean-Baptiste Velut

1 In the 1990s, the proliferation or consolidation of regional trade agreements in the Americas, Europe and Asia renewed century-old debates on the welfare effects of trade liberalization. ${ }^{1}$ In Canada, Mexico and the United States, the North American Free Trade Agreement (NAFTA), designed to liberalize trade and investment flows across the North American continent, crystallized tensions on the costs and benefits of free trade. These stormy controversies took decision-makers by surprise to the extent that NAFTA institutionalized a decade-long process of economic regionalization between North American economies. In effect, NAFTA was the sum of two bilateral relationships that converged in the United States. First, through a series of bilateral agreements reciprocal trade agreement (1935), Defense Production Sharing Agreement (1956) and the Auto Pact (1965) - culminating with the Canada-United States Free Trade Agreement of 1988, the American and Canadian economies had grown increasingly interdependent through the course of the twentieth century. Second, the gradual consolidation of the US-Mexican economic partnership through a series of initiatives like the Bracero Program (1943-1964), ${ }^{2}$ the creation of maquiladoras in 1965 and Washington's financial rescue plans during the Mexican debt crisis of the 1980s laid the ground for the signature of NAFTA. In this sense, NAFTA was only a logical step in the long process of economic rapprochement in North America. However, to a greater extent, NAFTA epitomized a power struggle for the future of globalization, pitting free trade advocates against an unprecedented coalition of labor, environmental, consumer and religious organizations that denounced the corporate bias of the agreement and its neglect for social and environmental issues. In the United States, the NAFTA debates heralded the beginning of a series of political battles on the rules of American trade policy (Velut, 2009). 
2 If the core logic of NAFTA was to liberalize trade flows between North American economies, the agreement was as much about liberalizing and protecting foreign investment as it was about dismantling trade barriers (Orme, 1996:126; Nishijima Smith, 1996:36). In this sense, NAFTA's investment provisions constituted the final phase in the restructuring of production processes on the North American continent. NAFTA also had long ramifications that would encroach upon national sovereignty in a number of spheres such as procurement policies or intellectual property rights. It was designed as a "contractual agreement" that would protect investors and companies through a strong dispute settlement mechanism (Deblock, Rioux 2010: 9-16).

3 In contrast, NAFTA's institutional framework largely left out important social issues that are nonetheless central to North American relations such as internal disparities or immigration. In addition, despite the efforts of unions and their allies, the agreement gave little scope to labor and environmental questions, which were confined to lowenforcement "side agreements," the purpose of which was to improve cooperation between the three member countries. ${ }^{3}$ Thus, while NAFTA can be considered as a classic case of regionalism (Mansfield, Milner op.cit.), it also constitutes a sui generis regional integration "model" developed primarily to maximize business efficiency through the reorganization of production processes on a continental scale (Coste, 2004:187-207; Eden, 1994). NAFTA members were reluctant to establish strong supranational institutions, in contrast with the deeper integration approach favored by European countries. ${ }^{4}$ The latter have adopted an ambitious agenda aimed at solving a set of common transnational problems in a variety of policy spheres. To do so, the European integration model rests upon a strong institutional apparatus that NAFTA undoubtedly lacks.

4 The narrow productivist logic of the NAFTA model along with the fierce controversies that surrounded its signature and ratification have made it a perfect case study to assess the linkage between trade liberalization and economic welfare. Since NAFTA came into force in 1994, numerous scholars have attempted to assess its socio-economic impact on North American economies. In congruence with the debates that preceded NAFTA's implementation, most studies of its impact have focused on sectoral dynamics (Robert, 2000; Burfisher Robinson Thierfielder, 2001: 125-144), employment (especially in the United States) (Ojeda, 2000; Haar, 2004: 55-67) and environmental questions (Gallagher, 2002: 119-141; Mann, Von Moltke, 1999).

5 Some analysts have examined NAFTA's socio-economic impact in Mexico in the prospect of determining whether the agreement can be interpreted as a successful or a failed development strategy. Easterly and his colleagues tend to side with the former conclusion, arguing that the income gap declined after 1995, even though convergence was partly hampered by Mexico's lack of institutional reforms (Easterly, Fiess, Lederman, 2003: 1-53). By contrast, Blecker and Esquivel, along with Wise, highlighted NAFTA's failure to meet the promises of its advocates by demonstrating that the income gap between US and Mexican workers had remained stable since NAFTA's passage(Blecker, Esquivel, 2010: 17-30; Wise, op.cit.). Findings on the evolution of social inequality in the post-NAFTA period are similarly contested. In 2003, Bizberg analyzed the political foundations of Mexico's export-oriented strategy and its repercussions on the labor market and pointed to a decline in real wages and an increase in income inequality (Bizberg, 2004: 69-85). However, two later studies by Campos-Vásquez and Esquivel concluded that income inequality had declined in the post-NAFTA period. Each 
study highlighted different factors that are not directly related to trade liberalization: a rise in college enrollment rates and a lack of demand for top-skilled jobs in the case of Campos-Vásquez; the implementation of new social programs, a growing flow of remittances as well as increasing education levels for Esquivel (Campos-Vasquez, 2010; Esquivel, 2010).

6 To bolster NAFTA's contested developmental record, scholars have offered either domestic or supranational solutions. Some have put the emphasis on domestic reforms in Mexico as a prerequisite for greater social cohesion within NAFTA (Wise, op.cit., Easterly, Fiess, Lederman, op.cit.), or a precondition for the adoption of supranational reforms (Hufbauer, Schott, op.cit.). Others have stressed the institutional weakness of NAFTA and admonish decision-makers to look to the European Union for supranational solutions to improve social cohesion across the North American continent (Studer, Pastor, op.cit.).

7 This article builds upon this literature with two objectives: clarifying the contrasted findings on NAFTA's socio-impact in Mexico during its first fifteen years of existence; second, providing a set of policy prescriptions to improve NAFTA's developmental record. In contrast with the early arguments of both free trade advocates and antiNAFTA critics, NAFTA's impact on Mexico has been neither a calamity nor a blessing. This means that the agreement should not be jettisoned; nor should it be relegated the bottom list of policymakers. Instead, the NAFTA model needs to be upgraded through both domestic and international reforms in order to respond to the old and new challenges that Mexico has had to face.

\section{Trade and investment under NAFTA}

Regardless of whether one embraces or condemns the effects of economic liberalization, it is hard to contest the fact that NAFTA has largely contributed to increase trade and investment flows between North American economies. In fifteen years, trade among the NAFTA partners more than tripled, from $\$ 289$ billion in 1993 to $\$ 945$ billion in 2008 (see figure 1) (Secretaria de Economia, 2010). This trend excludes the effect of the recent recession, which took a significant toll on trade flows at both global and regional levels. The Mexican economy directly benefited from this intensification of trade flows with its North American partners. 
Figure 1

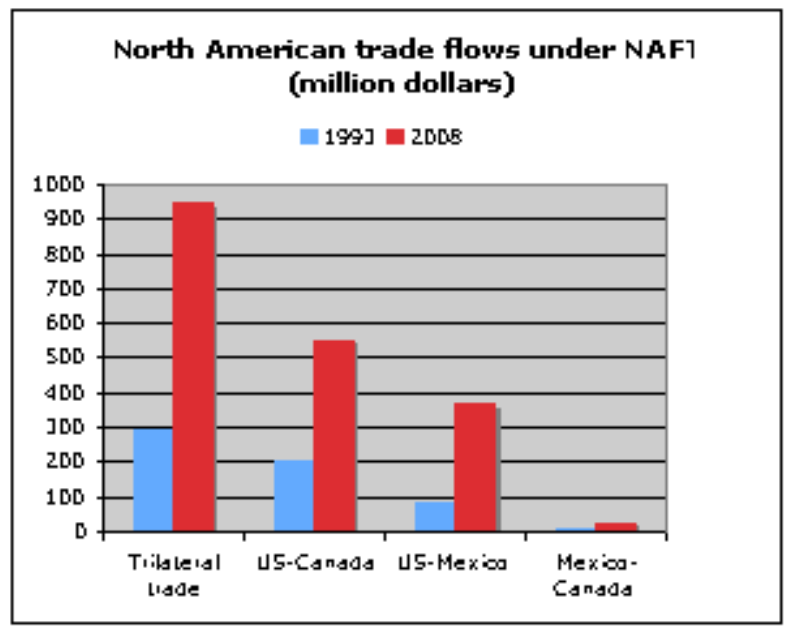

SOURCE: SECRETARÍA DE ECONOMÍA

Mexico converted its bilateral merchandise trade balance with the United States from a \$2-billion deficit in 1993 to a $\$ 74$-billion peak surplus in 2007 that would fall back to $\$ 48$ billion in 2009. Mexican exports to the US grew fivefold between 1993 and 2008 (from $\$ 40$ billion to $\$ 216$ billion), while its imports from America almost quadrupled ( $\$ 42$ billion to $\$ 151$ billion) (see figure 2).

Figure 2

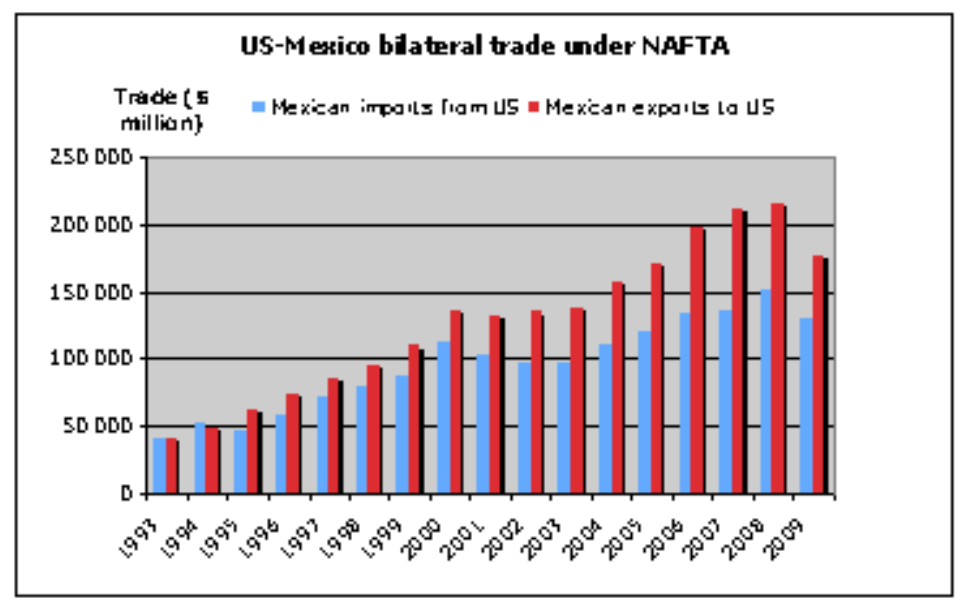

SOURCE: US CENSUS BUREAU

Through increased bilateral trade, the Mexican and American economies have become increasingly interdependent. In 2009, Mexico was the third largest trading partner of the United States, representing nearly 12\% of US trade in 2009 (against 16\% for Canada and $14 \%$ for China) (US Census Bureau, 2010). It absorbed almost one eighth of all U.S. exports and was the first or second export destination for twenty-two U.S. states (Wilson Center, 2009). Mexico is considerably dependent on the US economy, which accounted for $51 \%$ of Mexican imports and as much as $84 \%$ of its exports in 2009 . This makes Mexico largely vulnerable to economic recessions in the United States, as the recent crisis has shown. Based on foreign trade statistics from the Secretaría de Economía and the Banco de México, two thirds of the decline in Mexico's foreign trade in 2009 can 
be attributed to the downturn in US-Mexican bilateral trade (Secretaria de Economia, op.cit.).

Beyond the close economic ties between Mexico and the United States, Mexico's commercial relationship with Canada has also flourished under NAFTA. Despite its minor significance for North American trilateral trade (about 3\% in 2009), MexicanCanadian bilateral trade has surged six-fold over the past fifteen years (from $\$ 4$ billion in 1993 to $\$ 26$ billion in 2008). This has, once again, largely benefited Mexico, whose trade surplus jumped from \$2 billion in 1993 to $\$ 7$ billion in 2008 (Secretaria de Economia, op.cit.).

12 At the top of Mexico's export list are manufacturing goods ranging from auto parts to electronic goods like TV sets and telephones, oil and petrochemicals (INEGI, 2010). Mexican agricultural exports also increased under NAFTA, and particularly vegetables and fruit exports, which doubled from 1994 to 2005 (Zahniser, 2007: 23). The increase in non-oil exports was perhaps one of the most successful elements of Mexico's exportoriented strategy under NAFTA. According to Juan Carlos Moreno Brid, economist at the Economic Commission for Latin America and the Caribbean (CEPAL), Mexico experienced between 1994 and 2002 the second fastest rise in the share of world exports of manufacturing goods after China..$^{5}$ Mexican maquiladoras played a major role in the growth of the manufacturing sector, which was concentrated in no more than 300 firms often linked with multinational corporations. ${ }^{6}$

13 Admittedly, the performance of Mexico's exporting sector largely owes to the devaluation of its currency during the peso crisis of 1994-1995, which boosted the international competitiveness of Mexican exports. In addition, Mexico's trade expansion did not solely stem from NAFTA's implementation but was, to a larger extent, the result of a decade-old process of regional integration (Hufbauer, Goodrich, 2004: 37-50). However, NAFTA certainly boosted Mexico's exporting performance, particularly during the late 1990s.

14 Trade growth was propelled by a rise in investment flows on a regional level. Here again, the Mexican economy benefited from this trend, and particularly from the considerable surge in Foreign Direct Investment (FDI) not only from its NAFTA partners, but other competitors that sought to enter the North American market. Through a system of rules of origins, ${ }^{7}$ NAFTA encouraged firms from outside North America (especially Japanese, and more recently Chinese firms) to use Mexico as an exporting platform to the US market. Based on data from the United Nations Trade Conference on Trade and Development (UNCTAD), total FDI inward flows to Mexico more than tripled from an annual average of $\$ 3.5$ billion over the 1987-1993 period, to $\$ 12.4$ billion between 1994 and 2000, before reaching an annual level of $\$ 23.2$ billion dollars in 2001-2007. ${ }^{8}$ Total FDI stocks jumped from $\$ 41$ billion in 1993 to $\$ 295$ billion in 2008 (see figure 3). 


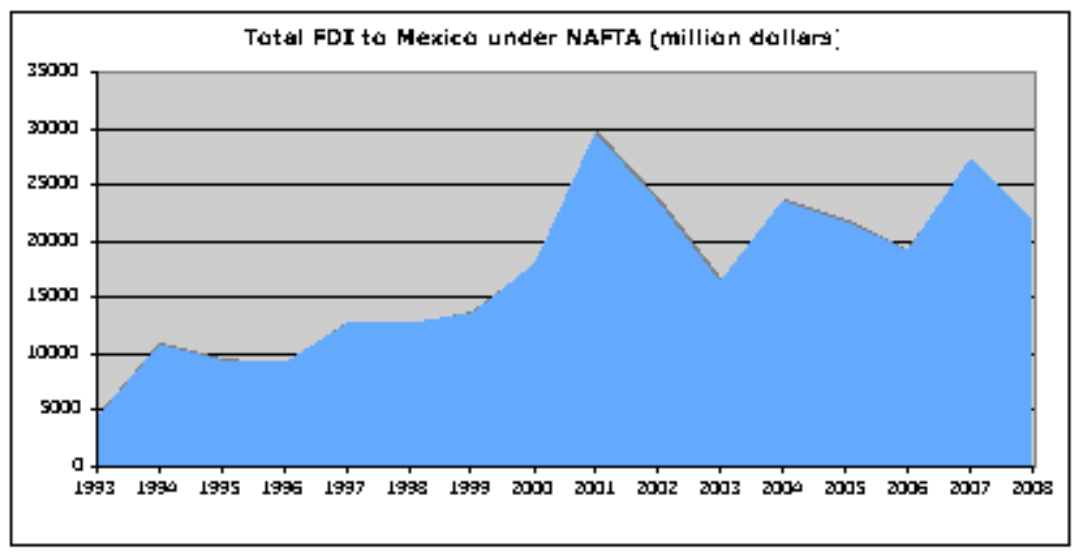

SOURCE: UNCTAD

15 The United States once again provided the lion's share of FDI inflows. In 2008, US FDI inflows accounted for $41 \%$ of total inflows to Mexico (rising up to $53 \%$ in 2009) benefiting more than 21,000 companies - along with $68 \%$ of the total amount invested in manufacturing, and $51 \%$ in the banking sector (US Embassy in Mexico; 2009). Canada's cumulative FDI paled in comparison with that provided by America, reaching \$9.8 billion over the 1994-2009 period (to 2,300 firms), yet amounted to nearly ten times as much as in 1994. Its FDI inflows to Mexico averaged \$617 million during NAFTA's first fifteen years (1994-2008) and represented 11\% of total inflows by 2008 ((Secretaria de Economia, op.cit.). This means that North American FDI accounted for three fifths of Mexico's FDI inflows in 2008. ${ }^{9}$ In short, NAFTA significantly accelerated the growth of regional trade and investment flows, to the benefit of the Mexican economy that became increasingly dependent on its North American trading partners.

\section{NAFTA's developmental legacy}

16 While NAFTA's macroeconomic consequences are clear, its socio-economic impact has been the subject of greater controversies. One main reason for these debates lies in the complexity of distinguishing what happened after NAFTA from what happened because of NAFTA. Determining NAFTA's direct effect on employment and wages is a difficult task to the extent that economic indicators are determined by a wide range of political and economic forces.

17 At first sight, the evolution of Mexico's social indicators after 1994 might suggest that NAFTA raised the prospects of Mexican households. Indeed, OECD statistics reveal that poverty receded after NAFTA came into force. Different measures of the poverty rate (under 60,50 or $40 \%$ of the current median income after taxes and transfers) all show a notable decline. Using the most common comparative indicator $(50 \%$ of median income), poverty declined from $21.7 \%$ in the mid-1990s to $18.4 \%$ in the mid-2000s. This contrasts with an increase in poverty in the decade that preceded NAFTA's implementation (from 20.7 to $21.7 \%$ ). Similarly, income inequality receded, with the Gini Index (after taxes and transfer) decreasing from 0.52 in the mid-1990s to 0.47 in the mid-2000s. Here again, post-NAFTA trends contrast with the rise of inequality in the decade before the agreement went into force, a period when the Gini Index jumped 
from 0.45 to 0.52 (OECD, 2010). This confirms the findings of Campos-Vásquez and Esquivel. Finally, Mexico's Human Development Index (HDI) - a composite indicator derived from data on health, education and income by the United Nations Development Programme (UNDP) - also rose after NAFTA. However, this indicator must be used with caution insofar as this upward trend has been constant since 1980 despite the severe crises from which Mexico suffered (United Nations Development programme, 2010).

A brief look at the employment picture in the post-NAFTA period reveals that the fears of NAFTA critics were exaggerated. According to statistics from the International Labor Organization (ILO), general employment in Mexico steadily increased during NAFTA's first fifteen years, adding 11 million jobs between 1993 and 2008 (from 33 to 44 million jobs). The official unemployment rate generally remained between 2.5 and 3.5\%, except in the aftermath of the peso crisis of 1994-1995, when it peaked at $6.9 \%$ in 1995 (International Labor Organization, 2010). Under closer scrutiny, however, Mexico's employment and development performance seems only partially affected by trade and investment flows. First, as figure 4 shows, there seems to be little correlation between total FDI inflows to Mexico and employment growth. For instance, the dramatic increase of FDI inflows in 1999-2001 (partly due to Citibank's acquisition of Banamex in $2001)^{10}$ did not have any significant effect on Mexico's labor market; nor did the erratic evolution of foreign investment after 2001 derail Mexico's slow but steady job growth.

Figure 4

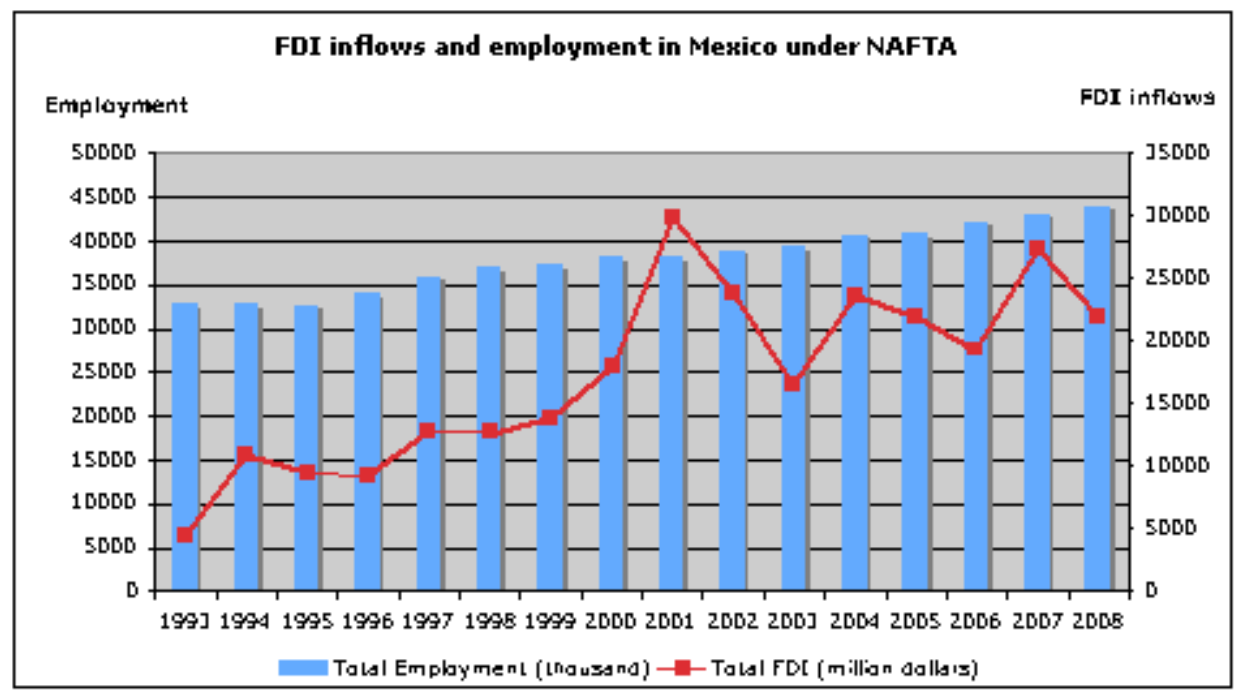

SOURCE: ILO, UNCTAD.

This finding dovetails with the conclusions reached by Blecker, who found that the rise in FDI in the post-NAFTA period has had no effect on Mexican growth (Blecker, 2009: 1274-1284). The limited gains accruing from the rise in FDI could be explained by the concomitant decline of Mexican domestic investment. Indeed, as Zepeda, Wise and Gallagher have shown, overall investment levels since NAFTA's implementation remained more or less stable after NAFTA's implementation, hovering around $19 \%$ of GDP during the 1994-2006 period (Zepeda, Wise, Gallagher, 2009:7).

If FDI inflows did not have a significant impact on job creation in Mexico, trade could have stimulated job growth. Mexico's rising exports to the United States under NAFTA and its employment performance seemed to be growing in sync between 1993 and 2008 
(see figure 5). But while it would be tempting to conclude that NAFTA has been an engine for job growth, NAFTA's employment record must be scrutinized in the two sectors most affected by trade liberalization: manufacturing and agriculture.

Figure 5

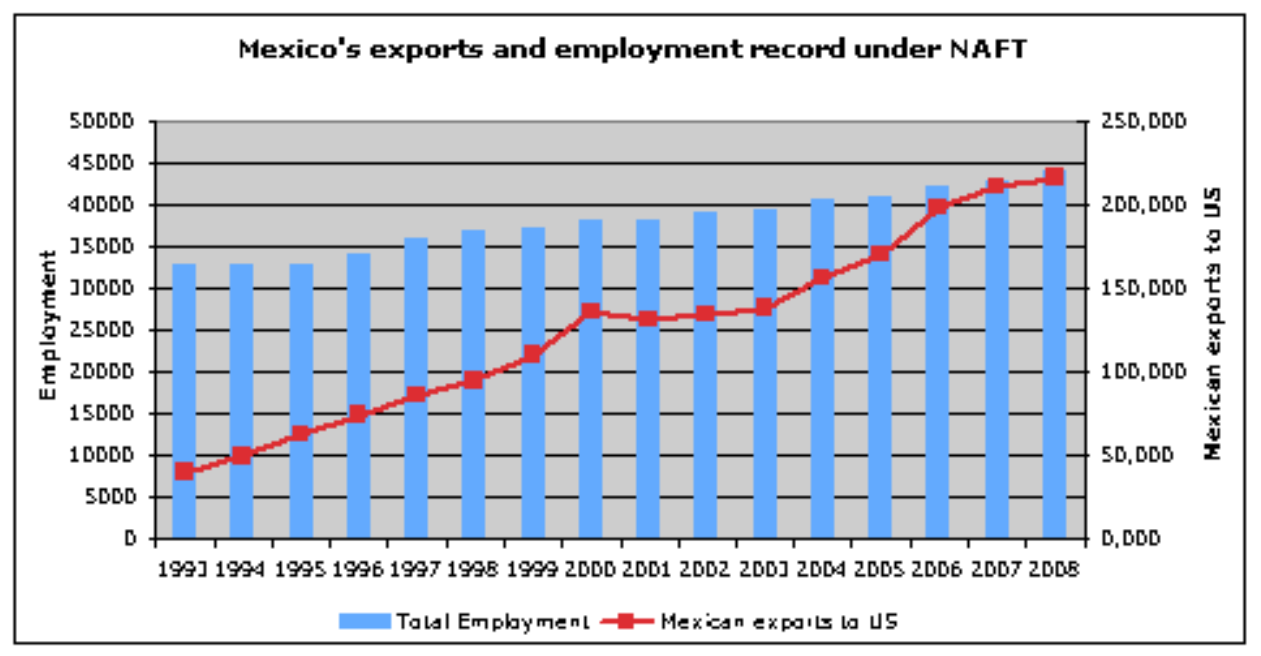

SOURCE: ILO, US CENSUS BUREAU.

\section{Mexico's manufacturing employment under NAFTA}

In the manufacturing sector, job creation mostly occurred in the first six years after NAFTA's implementation (1994-2000). Employment in the maquiladoras sector reached a peak of 1.3 million jobs in 2000 (on an annual basis) before receding to 1 million in 2003 (INEGI, 2007). In 2006, the last year for which data is available, ${ }^{11}$ it had not regained its 2000 level (1.2 million). Two factors explain this trend. First, and as previously mentioned, Mexico's exporting sector largely benefited from the devaluation of the peso until the early 2000s, when its exchange rate recovered. Secondly, after 2000, Mexican manufacturing companies faced increased competition from China. Boosted by its entry in the World Trade Organization in 2001 and a massive wave of investment flows from Western multinational corporations, China came to replace Mexico as America's leading manufacturing supplier, thereby taking over Mexico's rank as the US second trading partner. The recent recession and the corollary decline of American imports have not raised Mexico's prospects. As of this writing, the latest statistical survey of the new IMMEX program reveals that employment in Mexico's exporting sector (goods and services) declined by 17\% between July 2007 (beginning of the subprime crisis in the US) and July 2009 (from 1.910 to 1.578 million), before gradually recovering to reach 1.853 million in April 2011 (INEGI, 2009). This reveals, once again, the destabilizing effects of Mexico's dependency on the US economy.

One of the main promises of NAFTA advocates was the idea that liberalizing trade and investment flows across the continent would eventually reduce wage disparities between Mexico and its North American partners. However, fifteen years after NAFTA went into effect, Mexican living standards have hardly caught up with household income in America. Mexico's GDP per capita has remained roughly a sixth of that of the United States since the early 1990s (Wilson Center, op.cit.). The evolution of 
manufacturing wages shows a similar trend: in 1993, the average wage of American workers was 5.6 times higher than those of Mexican workers; in 2007, this ratio was at 5.8. In the maquiladoras - one of the sectors directly impacted by North American trade - real wages did increase after 1995. As revealed by the data from Mexico's Instituto Nacional de Estadística y Geografía (INEGI), this upward trend was particularly pronounced during the 2000-2009 period, when real wages increased by $17 \%$ (INEGI, op.cit.). In sum, employment and wage levels in the maquilas took diverging paths since NAFTA's implementation: between 1994 and 2000, employment increased and wages fell before slowly recovering; whereas in the first decade of the twenty-first century, wages rose while employment fell.

Mexico's sluggish employment record over the last fifteen years cannot, however, be attributed primarily to NAFTA. After the devaluation of the peso in 1994-1995, Mexican workers had to face the antagonistic pressures of rampant inflation of import goods and wage restrictions imposed by the federal government. This largely explains the decline of real wages from 1995 to the end of the 1990s and their delayed recovery under NAFTA. As mentioned before, the rise of China as a new industrial powerhouse also constituted a key challenge for Mexico's manufacturing exports. Thus, by itself, NAFTA has only had a limited impact on Mexican manufacturing employment. This is primarily due to the disconnect between Mexico's exporting sector and its domestic market. Indeed, because of the very low domestic content (only 5\%) (Carillo, 2010:27-43) of the goods transformed by maquiladoras, the spillover effects of Mexico's export strategy have been seriously constrained (Bizberg, op.cit.: 69-85). In short, NAFTA has neither led to a convergence between American and Mexican workers, nor spread its benefits to the rest of the economy. In fact, given the geographic location of the export-oriented manufactures, these limited gains are highly concentrated in the border-region, and therefore tend to exacerbate regional disparities in Mexico. In effect, states in Southern Mexico have remained isolated from the process of regional economic integration.

\section{NAFTA's impact on Mexican agriculture}

24 Any analysis of the evolution of Mexican agriculture under NAFTA should take into consideration two important contextual elements. First, the recent evolution of the agricultural sector reflects long-term structural transformations in the Mexican economy, as well as political reforms undertaken by successive Mexican governments since the 1980s, designed either to accelerate or respond to these changes. Second, it is important to emphasize the dichotomous nature of Mexico's farming sector, and more precisely, the distinction between small-scale and subsistence farming, and large-scale agribusiness.

A quick look at aggregate indicators reveals that Mexico's agricultural sector at least partly benefited from trade liberalization. As mentioned earlier, large-scale farmers in sectors like vegetable, fruit or meats production increased their exports to the United States and Canada. In these cases, NAFTA did help create more stable jobs and better living conditions. A recent study of the development of agribusiness in the borderregion of San Quintin shows that NAFTA not only helped to convert seasonal jobs into more permanent occupations, but also stimulated the local economy, thereby 
improving access to services like water, sanitary drainage and electricity (Coubes, 2010: 45-61).

This positive picture of Mexican agriculture under NAFTA does not, however, reflect the serious economic dislocations endured by Mexican farmers as a result of trade liberalization. Between 1993 and 2008, Mexican agricultural jobs slumped from 8.1 million to 5.8 million, a trend that largely offset job creation in the maquiladoras. By boosting US agricultural exports to Mexico, NAFTA had a significant impact on employment in the agrarian sector. Under NAFTA, the market share of American corn producers in Mexico jumped from an average of $15 \%$ over the $1984-1993$ period to about 35\% during 2001-2005 (Zahniser, op.cit.: 12). The influx of subsidized crops from American agribusiness had devastating effects on agricultural prices in Mexico and directly threatened the revenues of Mexican farmers. This was particularly the case with corn production, a crop on which $15 \%$ of the entire Mexican population still depends, according to some estimates (Burstein, 2007). Hardly concerned by the scale of this phenomenon, the Mexican government dismantled corn tariffs at a faster pace than required under NAFTA.

The first victims of these tectonic shifts were subsistence farmers. The liberalization of corn and other commodities is estimated to have reduced farm income for as many as three million small producers (Burstein, op.cit.). Given their low education level, campesinos were ill-equipped to transfer to other sectors of the economy. Some of them managed to integrate the service sector, whose share of the economy has significantly increased under NAFTA - from 51\% in 1994 to 60\% in 2006 (Polaski, 2006). Others were forced to join the ranks of the informal sector, consisting mainly of self-employment and employment in microenterprises. Yet others opted for migrating to the United States. Throughout the 1990s, the number of Mexican immigrants crossing the US border increased from about 350,000 per year before NAFTA to half a million in the early 2000s before declining significantly in the second half of the decade, partly under the effect of the financial crisis (Passel, Cohn, 2009; Zepeda, Wise, Gallagher, op.cit.: 13). In the words of one analyst, "migration has become an alternative to development." (Wilson Center, op.cit.: 26) These trends contrast with the early expectations of NAFTA's advocates, who anticipated that economic convergence between Mexico and the United States would reduce Mexicans' incentives to migrate to the North. This reveals the shortcomings of NAFTA's productivist model: under the demand of Washington, not only was immigration left out of the agreement, but no supranational mechanism was devised to address the social dislocations that would result from trade liberalization.

If no financial transfer mechanism was integrated in NAFTA, the Mexican government did seek to temper the disruptive effects of agricultural reforms through three assistance programs: 1) PROCAMPO, a transitional income support program for agricultural producers; 2) Alianza para el Campo, an initiative designed to foster agricultural productivity through matched grants and support services; 3) PROGRESA, the reallocation of food subsidies to the rural poor conditioned by the participation in basic education (for the relevant age group) and health services. But while these programs did provide some support for the rural poor, they also disproportionately favored Mexican agribusiness. According to the Economist magazine, PROCAMPO was "hijacked" early on by large-scale producers in the North, who received a large share of the program's $\$ 1.4$ billion (The Economist, 2008). This is ironic since this segment of 
Mexican agriculture was the primary beneficiary of agricultural liberalization under NAFTA; yet, somewhat understandable in the view of the government's tendency to prioritize the development of the export-oriented sector.

Three main conclusions emerge from this brief analysis of NAFTA's socio-economic impact. First, NAFTA should not be held responsible for all the deficiencies of the Mexican economy and its political system. An imbroglio of structural reforms in Mexico, "big events" (Easterly, Fiess, Lederman, op.cit.) like the peso crisis or the financial crisis of 2008-2009 as well as changing dynamics in the world economy have obscured NAFTA's real impact on the Mexican economy. Second, from a reductive business perspective, NAFTA achieved its core objectives of boosting FDI and international trade on a continental scale. This success, however, has been tarnished by the third lesson from NAFTA's 15-year existence, i.e. its failure to live up to the employment and development promises of its advocates. If poverty and social inequality have declined in the post-NAFTA era, the positive, albeit marginal effects of trade and investment liberalization on employment and wages in the manufacturing sector have been offset by the significant social dislocation experienced by poor farmers. As a result, economic convergence between Mexico and the United States has remained an elusive goal. This does not mean that NAFTA is a failed regional experiment. As the next section shows, NAFTA's social credentials could be restored with a combination of both domestic and supranational reforms.

\section{Making Nafta more development friendly}

The idea of reforming NAFTA might seem at odds with the original intent of NAFTA's architects. Some have argued that NAFTA was only designed to focus on strictly economic issues and should not be instrumentalized to strengthen the political axiom of the regional integration process, let alone to create a North American community. This was the implicit response that Washington and Ottawa gave to Mexican President Vicente Fox when the latter stressed the need to upgrade NAFTA through a series of reforms (dubbed "NAFTA-Plus") aiming primarily at liberalizing labor flows and creating a trinational compensation fund to assist the development of Mexico's poor regions. ${ }^{12}$ This refusal is emblematic of the discrepancy between the strict economic logic of the NAFTA model and the social repercussions of the North American integration process. Whether North American governments like it or not, trade liberalization has both transnational ramifications that affect each country's interests, as illustrated by the continuing flows of immigrants crossing the US border.

31 The limitations of NAFTA's productivist model have become increasingly clear in the light of the tectonic shifts of the world economy. The rapid growth of the Chinese manufacturing sector now threatens the viability of the North American competitive model, that some have declared to be "out of breath."(Deblock, Rioux, op.cit.) These new global forces make social reforms more, not less relevant for NAFTA countries.

\section{Consolidating domestic reforms}

For Mexican government officials, NAFTA's limited employment benefits during its first fifteen years of existence should have been a wake-up call about the limitations of export-led growth strategy as developmental policy. As mentioned earlier, it has long 
been clear that cross-border trade has only had marginal spillover effects on aggregate Mexican employment. This largely explains why employment gains under NAFTA before 2000 were concentrated in the maquiladoras, and why the limited wage increases in this sector did not spread to the rest of the Mexican workforce. Admittedly, the National Plan for Development (Programa Nacional de Desarollo) of 2001-2006 adopted under the Fox administration did stress the need to increase the value-added of the goods transformed in Mexico, and the necessity of strengthening the linkages between the exporting sector and local industries. However, as this analysis has shown, this has yet to bring benefits to the rest of the labor market. This program and the more recent creation (2006) of the export support initiative IMMEX confirm the importance that Mexican governments continue to give to international trade as a development tool. This is not to say that maquiladoras are an outdated economic model that needs to be abandoned. Indeed, maquilas have long proved to be both flexible and resilient in the face of external challenges (Carillo, op.cit.). However, Mexico's strategic focus on export-led growth is problematic in two regards: 1) it exacerbates Mexico's structural dependence on the US economy; 2) it distracts government officials from a pressing need to focus on domestic investment such as infrastructure and education.

The economic data discussed in the previous sections highlighted Mexico's cruel vulnerability to America's business cycles - whether this be the recession of 2001 or the financial crisis of 2008-2009. America's economic health does not only affect the performance of the Mexican economy through the decline of trade and investment flows, but also through the fluctuations of remittances from the United States. For instance, the recent crisis led to a decline of Mexican remittances of nearly one fifth, from $\$ 26$ billion in 2007 to $\$ 21$ billion in 2008 (Beaubien, 2010).

To cope with this problem, Mexico will need to find ways to diversify its sources of revenues, a long-lasting challenge that starts at home. As developmental specialists have long acknowledged, Mexico must begin by improving its chronically limited fiscal capacity by expanding its tax base. Indeed, as a proportion of GDP, Mexico's tax revenues are much lower than other OECD countries. ${ }^{13}$ President Calderon adopted a welcome step in this direction by raising corporate taxes in 2007. Another solution would be to prioritize the regulation of Mexico's informal economy, which not only limits tax collection but also tends to drag average wages down (Chen, 2008).

Another way to reduce Mexico's dependence on the US economy would consist in focusing on endogenous growth strategy, starting with increasing public investment in education and research and development (R\&D). Prioritizing education and training would help address some of NAFTA's shortcomings such as its inability to create employment in other sectors than manufacturing. Underinvestment in education has long been the Achilles' heel of the Mexican economy, a chronic weakness of which recent Mexican administrations have grown increasingly aware. The administration of Carlos Salinas de Gortari attempted to remedy the deficiencies of the Mexican education system by launching the Educational Modernization Program (1989-1994). Renewed under Salinas' successors, this program has achieved notable results in school enrollments, a success that contributed to the decline of social inequality in Mexico (Omelas, 2004: 285-306; Campos-Vasquez, op.cit.). Since 1997, President Zedillo's PROGRESA program, and its successor "Oportunidades" have also helped to boost access to education and health services among the rural and urban poor. ${ }^{14}$ These steps should be complemented with larger investment in higher education, as well as targeted 
research and development programs to increase Mexico's capacity for innovation. Emerging countries like India, China and South Korea have demonstrated the value of combining open trade with strong public investment in education - in schools, universities and R\&D programs (Gallagher, Zarsky, 2004).

Investing in infrastructure could also help mitigate NAFTA's tendency to exacerbate regional disparities between Northern states where export-industries tend to be concentrated and rural Southern states that are often disconnected from North American trade. President Fox's Puebla Panama Plan was an ambitious - albeit controversial ${ }^{15}$ - program regrouping a series of energy and infrastructure initiatives devised to connect Mexico's Southern states with Central American countries. Largely underfunded during Fox's presidency, the PPP has been revived by the Calderón administration and could offer the dual advantage of reducing regional inequalities and diversifying Mexico's economic partnerships. Mexico's ability to invest in infrastructure and education programs will depend on its ability to raise revenues, a challenge that could be surmounted by supranational programs.

\section{Reforming NAFTA}

Although Mexico's domestic reforms will be instrumental to improve NAFTA's developmental record, the scope of the North American accord should not be engraved in stone but left open to renegotiation. The long-term success of the NAFTA model will depend on the ability of its members to learn from their regional experience - or that of other integration models - and adapt the contours of the agreement to the new challenges of the world economy. This doesn't necessarily mean deepening North American integration. The problem with NAFTA lies not so much in its "institutional deficit" (Bellanger, 2004: 87-105) or its "deficient institutionality" (Grinspun Kreklewich, 1999: 17-33) per se - i.e. the absence of any supranational authority to enforce the rules of the agreement - but in its productivist bias which led North American governments to leave out the social ramifications of free trade. NAFTA's dispute settlement mechanism may not always protect investors and business interests as efficiently as NAFTA critics claim, ${ }^{16}$ but it remains undoubtedly better enforced and funded than e.g. the North American commission on labor cooperation (NACLC), NAFTA's only socially-oriented institution. ${ }^{17}$ Thus, the North American integration model suffers from its deficient social institutionality. This final subsection aims to offer a brief set of policy prescriptions that could consolidate NAFTA's social provisions and enhance its developmental potential. By no means exhaustive, this list focuses on four crucial issue areas: investment, agriculture, immigration, resource transfers.

First, Mexico could greatly benefit from a loosening of NAFTA's strict investment provisions. Although the protection of international investors is intrinsic to NAFTA, the devastating effects of US-based financial crises on Mexican exports and, to a broader extent, economic growth in Mexico, have demonstrated the deleterious side effects of the current model. To cope with this problem, the adoption of safeguards allowing a temporary return to stricter capital controls on foreign investment - e.g. modeled after those adopted by other emerging countries like China or Brazil - could protect Mexico against financial instability in times of crisis. In addition, a loosening of NAFTA's strict procurement and investment policies could allow Mexico to favor local contractors under certain circumstances e.g. in the regions that have hardly benefited from NAFTA 
(Zepeda, Wise, Gallagher, op.cit.). This could help mitigate the unequal effects that NAFTA has had on the Mexican economy.

The second issue area that has the potential to enhance NAFTA's developmental legacy is the contentious sphere of agricultural policy. In contradiction with the very principles of free trade, NAFTA fostered competition between small-scale and subsistence farming in Mexico and heavily subsidized American agribusiness companies. In fact, while Mexican governments strove to dismantle tariff protections at a faster pace than required by NAFTA's provisions until 2008, the US Congress repeatedly renewed and sometimes even increased its generous subsidies to the farming sector (through the Farm Bills 1996, 2002 and 2008). A 2009 study by the Global Development and Environment Institute estimated the costs for Mexico of "agricultural dumping under NAFTA" at $\$ 12.8$ billion over the 1997-2005 period. ${ }^{18}$ Losses to corn farmers accounted for nearly half of total costs. Considering the dramatic human effects that NAFTA had on Mexico's small-scale and subsistence farming, any developmental upgrade of the NAFTA model will have to make agricultural reform one its priorities. This does not necessarily mean that agricultural quotas should be reintroduced. Given the recent increase in commodity prices, hampering trade flows could hurt more poor people than it would protect. Bringing equity to the NAFTA model would require the progressive dismantling of American agricultural subsidies, starting with those supporting large agribusinesses, which absorb the lion's share of American subsidies. If the idea may seem politically unfeasible, the recent debates on the long-term reduction of the US national debt could provide new opportunities to address this long-lasting issue.

The displacement of Mexican farmers is interconnected with the question of immigration. International migration has always been a key factor of international economic convergence, whether it be transatlantic migration at the end of the nineteenth century and its positive effects on European wages, or the economic benefits of labor market integration in the European Union. ${ }^{19}$ Given the intense labor flows within North America, immigration should be an integral part of any attempt to make NAFTA more development-friendly - as former President Vicente Fox has long claimed. In North America, the free movement of workers would be a noble long-term goal, but is in the short run nothing but a chimera. In the meantime, North American governments should seek to optimize the developmental potential of transnational labor flows, first by protecting migrants, and second, by encouraging resource transfers under a new trilateral remittance policy.

One way to address NAFTA's deficient social institutionality would be to adhere to the strict enforcement of labor standards in North America. This is not only important for the protection of workers in Mexico, as "fair trade" advocates have long advocated, but also applies to the protection of authorized and unauthorized immigrants in the United States, whose low wages can have a depreciating effect on the revenues of low-skilled workers.

42 Another way to tap the developmental power of labor flows would be to develop an effective trilateral remittance policy. While remittances are no substitute for domestic investment and government assistance to the needy, they are also more politically palatable than foreign aid. North American states should capitalize on the recent shift of remittances from the informal to the formal sector and undertake collective efforts to secure and reduce the costs of such financial transfers. Such measures could include 
harmonizing regulations between state/provincial and federal authorities, ensuring fair competition (e.g. transparent pricing) in the banking sector, supporting the development of distribution networks in rural regions where access to remittance services are often limited, as well as experimenting tax deductions for resource transfers toward underdeveloped regions. ${ }^{20}$

Finally, overcoming the political hurdles that stand in the way of the long-term integration of North American labor markets will also require changing the image of immigration to create a new form of solidarity between North American citizens. One solution could be to intensify higher-education exchange programs and high-skilled temporary visas to encourage knowledge transfers between Mexico and its North American partners. This is crucial to alter the common representation of Mexicans as low-skilled workers. Exchange programs like Erasmus in Europe have proved very successful in changing people's representations and could help foster North American solidarity.

Perhaps the most promising reform to improve NAFTA's developmental legacy would be the creation of a regional compensation fund - an initiative long embraced by advocates of regional integration in both government and academic circles. Modeled after the European Union's structural and cohesion funds, this program could reduce regional disparities between NAFTA members. Europe's experience has shown that trade and investment liberalization alone cannot achieve economic convergence. Leaving aside the recent impact of the financial crisis, the rapid growth of Ireland, Spain and Portugal over the past decades has shown the merits of transfer programs as pivotal components of regional economic integration. ${ }^{21}$ In the case of Mexico, resource transfers could help invest in transport and communication infrastructure as well as education in Mexico's poorest states. These new investments would not only stimulate job creation but could also help connect rural communities with the rest of the North American economic sphere. Of course, it is easy to anticipate opposition in the US Congress against funding such resource transfer programs, especially in the current context of budget cuts. To be more politically palatable, the North American development fund must be presented for what it truly is: a policy that addresses the root problems of immigration and drug trafficking, two endemic problems of North American relations that have cost the United States billions of dollars during NAFTA's fifteen years of existence. This initiative would certainly depart from NAFTA's current productivist logic, yet could also help North American governments address the issues that have tarnished the reputation of NAFTA.

\section{Conclusion}

To conclude, NAFTA has undeniably boosted trade and investment among North American partners. At first sight, the Mexican economy seems to have benefited from the process of regional economic integration. Yet, a closer look at employment and wage trends shows that NAFTA has in fact done little to foster equitable development in Mexico. Its impact on Mexico's manufacturing sector has been in effect positive albeit limited; yet it has largely been offset by the adjustment shocks of trade liberalization in the agricultural sector. Some will argue that NAFTA was never designed to solve all of Mexico's problems and that the agreement has, after all, achieved its objectives of boosting trade and investment flows (Hufbauer, Schott, op.cit.). However, the rise in 
international trade should not be the ultimate goal of regional economic integration, but rather a means of building a more prosperous regional economy that benefit the citizens of all NAFTA countries.

NAFTA's mixed results in the social realm can be partly attributed to the shortcomings of Mexico's domestic policies. To maximize the socio-economic potential of the North American integration model, Mexican decision-makers may have to rethink their focus on export-led growth and prioritize domestic policies aimed at investing in Mexico's future, through education, R\&D and infrastructure. Beyond Mexico's domestic policies, NAFTA's shortcomings are due to its narrow productivist logic. To remedy this problem, North American governments should address NAFTA's deficient social institutionality through a series of measures that would target some of the most pressing social issues, among which immigration, agriculture and resource transfers. Although NAFTA is not the solution to all of Mexico's problems, it is embedded in the process of regional economic integration and has, therefore, come to incarnate the benefits, but also the costs of regionalism. Failing to address the social needs that are inherent to trade and investment liberalization risks undermining people's already fragile confidence in a regional integration process that North American countries have been building for decades.

\section{BIBLIOGRAPHIE}

Baldwin, Richard \& Charles Wyplosz, The Economics of European Integration, London: McGraw Hill Companies, 2006.

Beaubien, Jason, “Mexico Suffers As U.S. Economy Struggles," National Public Radio, February $10^{\text {th }}, 2010$. http://www.npr.org/templates/story/story.php?storyId=123373874. Accessed March $1^{\text {st }}, 2010$.

Bhagwati, Jagdish N. \& Arvind Panagariya, The Economics of Preferential Trade Agreements Washington, D.C.: AEI Press, 1996.

Bizberg, Ilán, « Le Mexique et l'ALENA : inégalités et démocratie » in Martine Azuelos, María Eugenia Cosío-Zavala \& Jean-Michel Lacroix, Intégration dans les Amériques. Dix ans d'ALENA, Paris : Presse Sorbonne Nouvelle, 2004, pp. 69-85.

Blecker, Robert A., "External Shocks, Structural Change, and Economic Growth in Mexico," World Development, vol. 37, $\mathrm{n}^{\circ}$ 7, 2009, pp. 1274-1284.

Burfisher, Mary E., Sherman Robinson \& Karen Thierfelder, "The Impact of NAFTA on the United States", Journal of Economic Perspectives, vol. 15, n¹, 2001, pp. 125-144.

Burstein, John, "U.S.-Mexico Agricultural Trade and Rural Poverty in Mexico," Woodrow Wilson Center, April 13 ${ }^{\text {th }}, 2007$. http://wilsoncenter.org/topics/pubs/

Mexico_Agriculture_rpt_English1.pdf. Accessed March 1 $1^{\text {st }}, 2010$. 
Campos-Vásquez, Raymundo M., "Why Did Wage Inequality Decrease in Mexico After NAFTA?", Serie documentos de trabajo del Centro de Estudios Económicos, n¹5, 2010. http:// econpapers.repec.org/paper/emxceedoc/2010-15.htm. Accessed July 27, 2011.

Carillo, Jorge, « Les générations d'entreprises maquiladoras. Une analyse critique, » Cahiers des Amériques Latines, $\mathrm{n}^{\circ} 56,2010$, pp. 27-43.

Chen, Marty, “Addressing Informality, Reducing Poverty," Poverty in Focus, $\mathrm{N}^{\circ} 16$, International Poverty Centre, December, 2008. http://www.ipc-undp.org/pub/IPCPovertyInFocus16.pdf. Accessed March 1st, 2010.

Coste, Jacques-Henri, "Les entreprises américaines, acteurs d'intégration" in Martine Azuelos, María Eugenia Cosío-Zavala \& Jean-Michel Lacroix, Intégration dans les Amériques. Dix ans d'ALENA, Paris : Presse Sorbonne Nouvelle, 2004, pp. 187-207.

Coubès, Marie-Laure, “Agriculture pour l'exportation et peuplement rural dans la région frontalière Mexique/ États-Unis San Quintin en Basse Californie," Cahiers des Amériques Latines, n56, 2010, pp. 45-61.

Deblock, Christian \& Michèle Rioux, "NAFTA - A Model Running Out of Breath?", CESifo Forum, Vol. 11, n4 2010, pp. 9-16.

Easterly, William, Norbert Fiess, \& Daniel Lederman, "NAFTA and Convergence in North America: High Expectations, Big Events, Little Time,” Economía, Vol. 4, º1, 2003, pp. 1-53.

The Economist, “Tariffs and Tortillas," January $24^{\text {th }}, 2008$. http://www.ase.tufts.edu/gdae/Pubs/ wp/09-08AgricDumping.pdf. Accessed March 1st, 2010.

Eden, Lorraine (ed.), Multinationals in North America, Calgary: Calgary University Press, 1994.

Esquivel, Gerardo, "The Dynamics of Income Inequality in Mexico Since NAFTA", Serie documentos de trabajo del Centro de Estudios Económicos, vol. 9, 2010.

Gallagher, Kevin. P., "Industrial Pollution in Mexico: Did the NAFTA Matter?” in Caroline L. Deere, and Daniel C. Esty (eds.), Greening the Americas. NAFTA's Lessons for Hemispheric Trade, Cambridge: The MIT Press, 2002, pp. 119-141.

Gallagher, Kevin P. \& Lyuba Zarsky, "Sustainable Industrial Development? The Performance of Mexico's FDI-led Integration Strategy," Global Development and Environment Institute, Tufts University, 2004. http://ase.tufts.edu/gdae/pubs/rp/mexicofdireport11-03.pdf. Accessed March $1^{\text {st }}, 2010$.

Grinspun, Ricardo \& Robert Kreklewich, "Institutions, Power Relations, and Unequal Integration in the Americas: NAFTA as Deficient Institutionality", in Kristen Appendini \& Sven Bislev (eds.), Economic Integration in NAFTA and the EU, New York: St. Martin Press, 1999, pp. 17-33.

Haar, Jerry, "L'ALENA et le travailleur américain”, in Martine Azuelos, María Eugenia CosíoZavala \& Jean-Michel Lacroix, Intégration dans les Amériques. Dix ans d'ALENA, Paris : Presse Sorbonne Nouvelle, 2004, pp. 55-67.

Hernández-Coss, Raúl, "The US-Mexico Remittance Corridor. Lessons on Shifting from Informal to Formal Transfer Systems", World Bank Working Paper N47, 2005, http:// siteresources.worldbank.org/EXTAML/Resources/396511-1146581427871/USMexico_Remittance_Corridor_WP.pdf. Accessed August, 14th, 2011.

Hinojosa Ojeda, R., et al. The US Employment Impacts of North American Integration After NAFTA: A Partial Equilibrium. Los Angeles: North American Integration and Development Center, 2000. 
Hufbauer, Gary C. \& Ben Goodrich, "Lessons from NAFTA," in Jeffrey J. Schott (ed.), Free Trade Agreements. US Strategies and Priorities, Washington DC: Institute for International Economics, 2004, pp. 37-50.

Hufbauer, Gary C. \& Jeffrey J. Schott, NAFTA Revisited. Achievements and Challenges. Washington, DC: Institute for International Economics, 2005.

Instituto Nacional de Estadística y Geografía (INEGI), "Industria maquiladora de exportación," February 2007. http://www.inegi.org.mx/prod_serv/contenidos/espanol/bvinegi/productos/ continuas/economicas/maquiladora/ime/ime.pdf. Accessed March $1^{\text {st }} 2010$.

INEGI, “Estadística del Programa del Programa de la Industria Manufacturera, Maquiladora y de Servicios de Exportación (IMMEX)", 2009. http://www.inegi.org.mx/est/contenidos/espanol/ proyectos/INMEX/Información_seleccionada_IMMEX.pdf. Accessed March 1 ${ }^{\text {st }}, 2010$.

INEGI, “Balanza comercial de México,” January 2010.

http://www.inegi.org.mx/prod_serv/contenidos/espanol/bvinegi/productos/continuas/ economicas/exterior/mensual/bcm/bcm.pdf. Accessed March $1^{\text {st }}, 2010$.

International Labor Organization, “Laborsta Internet”, 2010, http://laborsta.ilo.org. Accessed July 28, 2011.

Irwin, Douglas, Against the Tide. An Intellectual History of Free Trade, Princeton: Princeton University Press, 1996.

Mann, Howard, and Konrad von Moltke, NAFTA's Chapter 11 and the Environment: Addressing the Impacts of the Investor-State Process on the Environment, Winnipeg: International Institute for Sustainable Development, 1999.

Mansfield, Edward D. \& Helen Milner, "The New Wave of Regionalism," International Organization, vol. 53, n³, 1999, pp. 589-627.

Martinez-Vazquez, Jorge \& Duanjie Chen, "The Impact of NAFTA and Options for Tax Reform in Mexico," World Bank Policy Research Working Paper 2669, September 2001. http://wwwwds.worldbank.org/external/default/WDSContentServer/IW3P/IB/ 2001/10/05/000094946_01092504010964/Rendered/PDF/multiopage.pdf. Accessed March $1^{\text {st }}$, 2010.

Mayer, Frederick M., Interpreting NAFTA. The Science and Art of Political Analysis, New York: Columbia University Press, 1998.

Moreno-Brid, Juan Carlos "Economic Development and Industrial Performance in Mexico postNAFTA," CEPAL, 2007. http://www.eclac.org/celade/noticias/paginas/3/28353/JCMoreno.pdf. Accessed March 1 $1^{\text {st }}, 2010$.

Moro, Braulio, “Une recolonisation nommée "plan Puebla-Panamá", Le Monde Diplomatique, Décembre 2002. http://www.monde-diplomatique.fr/2002/12/MORO/17151. Accessed August $10^{\text {th }}, 2011$.

Nishijima, Shoji \& Peter H. Smith (eds, Cooperation or Rivalry? Regional Integration in the Americas and the Pacific Rim, Boulder: Westview Press.), 1996.

Organisation for Economic Development and Co-operation, "Income Distribution - Inequality", OECD.StatExtracts, 2010, http://stats.oecd.org/Index.aspx. Accessed July 28, 2011.

Orme, William A, Understanding NAFTA. Mexico, Free Trade and the New North America, Austin: University of Texas Press., 1996. 
Ornelas, Carlos, "NAFTA and Mexican Higher Education" in Sidney Weintraub (ed.), NAFTA's Impact on North America: The First Decade, Washington, D.C.: Center for Strategic and International Studies Press, 2004, pp. 285-306.

Passel, Jeffrey S. \& D’Vera Cohn. “Mexican Immigrants: How Many Come? How Many Leave?” Washington, DC: Pew Hispanic Center, July 2009. http://pewhispanic.org/files/reports/112.pdf. Accessed March 1st, 2010.

Pastor, Robert A., Toward a North American Community. Lessons from the Old World for the New, Washington, DC: Institute for International Economics, 2001.

Polaski, Sandra, "The Employment Consequences of NAFTA," Carnegie Endowment for International Peace, Testimony submitted to the Senate Subcommittee on International Trade of the Committee on Finance, September 11, 2006. http://www.carnegieendowment.org/files/ naftawrittentestimony.pdf. Accessed March 1st, 2010.

Robert, Maryse, Negociating NAFTA. Explaining the Outcome in Culture, Textiles, Autos and Pharmaceuticals, Toronto/Buffalo/London: University of Toronto Press, 2000.

Secretaria de Desarrollo Social, "External Evaluation of Oportunidades 1997-2007: 10 Years of Intervention in Rural Areas.”, 2008 lanic.utexas.edu/project/etext/oportunidades/2008/ sariego_eng.pdf. Accessed March 1st, 2010.

Secretaria de Economía, “Mexico-Canada Trade and Investment from Canada in Mexico," January 2010. http://www.economia-snci.gob.mx/sic_php/pages/files_varios/pdfs/Can_Sep09.pdf. Accessed March 1 ${ }^{\text {st }}, 2010$.

Secretaria de Economía, Dirección General de Inversión Extranjera, 2010. http://www.sirnie.economia.gob.mx/cgi-bin/repie.sh/reportes/selperiodo. Accessed March $1^{\text {st }}, 2010$.

Secretaria de Economía, Subsecretaria de Negociaciones Comerciales Internacionales, 2010. http://www.economia.gob.mx/?P=5400. Accessed March $1^{\text {st }}, 2010$.

Secretaria de Economía, Representación de la Secretaria de Economía en Canadá, January 2010. http://www.economia-snci.gob.mx/sic_php/pages/files_varios/pdfs/Can_Sep09.pdf. Accessed March $1^{\text {st }}, 2010$.

Isabel Studer, “Obstacles to Integration. NAFTA's Institutional Weakness", in Isabel Studer \& Carol Wise (eds.), Requiem or Revival? The Promise of North American Integration, Washington, DC: Brookings Institution, pp. 53-75.

Studer, Isabel \& Carol Wise (eds.), Requiem or Revival? The Promise of North American Integration, Washington, DC: Brookings Institution Press, 2007.

United Nations Conference on Trade and Development (UNCTAD), "World Investment Report 2009," http://unctad.org/en/docs/wir2009_en.pdf. Accessed March 1 $1^{\text {st }}, 2010$.

United Nations Development Programme, “International Human Development Indicators Mexico", 2010, http://hdrstats.undp.org/en/countries/profiles/MEX.html. Accessed July 28, 2011.

United States Census Bureau, "Foreign Trade Statistics. Total Trade, Exports, Imports," February 10th. 2010. http://www.census.gov/foreign-trade/statistics/highlights/top/top0912yr.html. Accessed March 1 $1^{\text {st }}, 2010$.

United States Embassy in Mexico, “U.S. - Mexico At a Glance," June, 2009. http:// www.usembassy-mexico.gov/eng/eataglance_trade_FDI.pdf. Accessed March $1^{\text {st }}, 2010$. 
Velut, Jean-Baptiste, "Free" or "Fair" Trade? The Battles for the Rules of American Trade Policy from NAFTA to CAFTA (1991-2005), Unpublished doctoral dissertation (City University of New York/ Sorbonne Nouvelle University), 2009.

Viner, Jacob, The Customs Union Issue, New York: Carnegie Endowment for International Peace, 1950.

Wise, Carol, "Unfulfilled Promise. Economic Convergence under NAFTA", in Isabel Studer \& Carol Wise (eds.), Requiem or Revival? The Promise of North American Integration, Washington, DC: Brookings Institution, 2007, pp. 27-52.

Wise, Timothy A., “Agricultural Dumping Under NAFTA: Estimating the Costs of U.S. Agricultural Policies to Mexican Producers," Global Development and Environment Institute, Working Paper N09-08, 2009, Woodrow Wilson Center. http://ase.tufts.edu/gdae/Pubs/rp/ AgricDumpingWoodrowWilsonCenter.pdf. Accessed March 1st, 2010.

Woodrow Wilson Center, "The United States and Mexico: Towards a Strategic Partnership," January 2009. http://www.wilsoncenter.org/topics/pubs/The\%20U.S.\%20and\%20Mexico. \%20Towards\%20a\%20Strategic\%20Partnership.pdf. Accessed March $1^{\text {st }}, 2010$.

Zahniser, Steven, "NAFTA at 13. Implementation Nears Completion," US Department of Agriculture, March 2007. http://www.ers.usda.gov/publications/wrs0701/wrs0701.pdf. Accessed March 1 $1^{\text {st }}, 2010$.

Zepeda, Eduardo, Timothy A. Wise \& Kevin P. Gallagher, "Rethinking Trade Policy for Development: Lessons from Mexico Under NAFTA," Carnegie Endowment for International Peace, December 2009. http://carnegieendowment.org/files/nafta_trade_development.pdf. Accessed March 1st, 2010.

Zumello, Christine, « Les banques américaines et l'ALENA : le cas de Citibank », in Martine Azuelos, María Eugenia Cosío-Zavala \& Jean-Michel Lacroix, Intégration dans les Amériques. Dix ans d'ALENA, Paris : Presse Sorbonne Nouvelle, 2004, pp. 209-220.

\section{NOTES}

1. This question can be traced back to early debates on liberalism and mercantilism. For a history of free debates, see Douglas Irwin, Against the Tide. An Intellectual History of Free Trade, Princeton: Princeton University Press, 1996. For a discussion of the welfare effects of trade agreements, see among others, Jacob Viner, The Customs Union Issue, New York: Carnegie Endowment for International Peace, 1950; Jagdish N. Bhagwati \& Arvind Panagariya, The Economics of Preferential Trade Agreements Washington, D.C.: AEI Press, 1996; Edward D. Mansfield \& Helen Milner, "The New Wave of Regionalism", International Organization, vol. 53, n³, 1999, pp. 589-627.

2. The Bracero Program invited hundreds of thousands of Mexican farm workers to offset America's labor shortage in the agricultural sector.

3. Although they did create precedents to the linkage of trade and labor and especially environmental issues, these agreements were primarily conceived as side payments to appease and divide NAFTA opponents. Frederick M. Mayer, Interpreting NAFTA. The Science and Art of Political Analysis, New York: Columbia University Press, 1998.

4. For a broader discussion of NAFTA as regional model, see Robert A. Pastor, Toward a North American Community. Lessons from the old World for the New, Washington, DC: Institute for International Economics, 2001, pp. 25-33; Carol Wise, "Unfulfilled Promise. Economic Convergence under NAFTA", in Isabel Studer \& Carol Wise (eds.), Requiem or Revival? The Promise of 
North American Integration, Washington, DC: Brookings Institution, 2007, pp. 29-32; Isabel Studer, "Obstacles to Integration. NAFTA's Institutional Weakness", in Isabel Studer \& Carol Wise (eds.), op. cit., pp. 54-58; and Christian Deblock \& Michèle Rioux, op. cit.

5. Mexico ranked only fifth on the 1985-1994 period. Juan Carlos Moreno-Brid, "Economic Development and Industrial Performance in Mexico post-NAFTA," CEPAL, 2007. http:// www.eclac.org/celade/noticias/paginas/3/28353/JCMoreno.pdf. Accessed March $1^{\text {st }}, 2010$.

6. Ibid.

7. Rules of origins restrict preferential tariffs to merchandise principally produced in the contracting parties to a trade agreement. For instance, within the framework of NAFTA, $62.5 \%$ of auto components must be made in North America in order for cars to qualify for tariff exemption. These clauses aim to protect firms against external competition, especially Asian firms that might benefit from NAFTA's provisions to enter the US market.

8. Author's calculations based on data from United Nations Conference on Trade and Development (UNCTAD), “World Investment Report 2009," http://unctad.org/en/docs/ wir2009_en.pdf. Accessed March 15 2010.

9. In 2008, FDI inflows were distributed as follows: manufacturing sector including maquiladoras (40\%), services (20\%), oil and mining extraction (18\%), trading (13\%). Secretaria de Economía, Dirección General de Inversión Extranjera, 2010, http://www.si-rnie.economia.gob.mx/cgi-bin/ repie.sh/reportes/selperiodo. Accessed March $1^{\text {st }}, 2010$.

10. For more details, see Christine Zumello, «Les banques américaines et l'ALENA : le cas de Citibank », in Martine Azuelos, María Eugenia Cosío-Zavala \& Jean-Michel Lacroix, op. cit., pp. 209-220.

11. At the end of 2006, Mexico's National Institute of Statistics and Geography (INEGI) replaced its statistical series on maquiladoras with statistics on a new export support program called IMMEX (Fomento de la Industria Manufacturera, Maquiladora y de Servicios de Exportacion - Promotion of manufacturing industry, maquiladora and export services): Juan Carlos Moreno-Brid, op. cit.

12. For a discussion, read Isabel Studer, op. cit.; and Robert Pastor, pp. 2-3.

13. For more details on tax reform, see Jorge Martinez-Vazquez and Duanjie Chen, "The Impact of NAFTA and Options for Tax Reform in Mexico," World Bank Policy Research Working Paper N²669, September 2001.

http://www-wds.worldbank.org/external/default/WDSContentServer/IW3P/IB/

2001/10/05/000094946_01092504010964/Rendered/PDF/multi0page.pdf. Accessed March $1^{\text {st }}$, 2010.

14. Designed for the rural poor, PROGRESA was extended to semi-urban and urban populations in 2001 and 2002 respectively. Today, 5 million families benefit from Oportunidades. For a 10-year assessment of this education program, see Secretaria de Desarrollo Social, "External Evaluation of Oportunidades 1997-2007: 10 Years of Intervention in Rural Areas," 2008. lanic.utexas.edu/ project/etext/oportunidades/2008/sariego_eng.pdf. Accessed March 1st, 2010.

15. The plan raised concerns about the privatization of land and resources. See e.g. Braulio Moro, "Une recolonisation nommée "plan Puebla-Panamá", Le Monde Diplomatique, Décembre 2002. http://www.monde-diplomatique.fr/2002/12/MORO/17151. Accessed August 10 $0^{\text {th }}, 2011$.

16. For a discussion, see Gary C. Hufbauer \& Jeffrey J. Schott, op. cit., chapter 4.

17. This institution emanated from the "toothless" labor side agreement. See footnote 3.

18. The author focused on eight agricultural goods - corn, soybeans, wheat, rice, cotton, beef, pork, and poultry - heavily supported by the U.S. government, and which dramatically affected Mexican production under NAFTA. Timothy A. Wise, "Agricultural Dumping Under NAFTA: Estimating the Costs of U.S. Agricultural Policies to Mexican Producers," Global Development and Environment Institute, Working Paper N09-08, Woodrow Wilson Center. http://ase.tufts.edu/ gdae/Pubs/rp/AgricDumpingWoodrowWilsonCenter.pdf. Accessed March 1st, 2010. 
19. On the economics of labor market integration, read Richard Baldwin \& Charles Wyplosz, The Economics of European Integration, London: McGraw Hill Companies, 2006, pp. 190-193.

20. For a broader discussion, see Raúl Hernández-Coss, The US-Mexico Remittance Corridor. Lessons on Shifting from Informal to Formal Transfer Systems, World Bank Working Paper $\mathrm{N}^{\circ} 47$, 2005, http://siteresources.worldbank.org/EXTAML/Resources/396511-1146581427871/USMexico_Remittance_Corridor_WP.pdf. Accessed August, 14th, 2011.

21. As Pastor rightly points out by contrasting the examples of Ireland and Greece, the success of such financial transfers is contingent upon the implementation of effective domestic reforms. Robert Pastor, op. cit., p. 135.

\section{RÉSUMÉS}

Cet article dresse le bilan socio-économique de l'Accord de libre-échange nord-américain (ALENA) pour le Mexique quinze ans après son entrée en vigueur. À travers une analyse de l'évolution des flux de capitaux et de commerce et de leur impact sur l'emploi et le niveau des salaires dans les secteurs industriels et agricoles, l'auteur révèle les succès et limites du modèle d'intégration de l'ALENA. Il conclut que si l'ALENA n'est pas une solution à tous les problèmes socio-économiques du Mexique, l'accord souffre malgré tout d'une "institutionalité [sociale] déficiente" qui peut être consolidée par le biais de réformes nationales et supranationales. Au niveau national, le gouvernement mexicain doit repenser sa stratégie de croissance tirée par les exportations et donner la priorité à la réforme fiscale et aux investissements dans l'éducation et l'infrastructure. À l'échelle supranationale, le modèle de l'ALENA devrait être amélioré afin de combler ses lacunes sociales, en particulier dans les domaines de l'investissement, l'immigration, l'agriculture et des transferts de ressources.

This article assesses the developmental record of the North American Free Trade Agreement (NAFTA) in Mexico fifteen years after its implementation. After analyzing the evolution of trade and investment flows and their impact on employment and wage levels in the manufacturing and agricultural sectors, the author highlights the success and limits of the NAFTA integration model. He concludes that while NAFTA should not be seen as a solution to all of Mexico's socio-economic problems, NAFTA nonetheless suffers from a "deficient [social] institutionality" that can be addressed through both domestic and supranational reforms. At the domestic level, the Mexican government should rethink its export-led growth strategy and prioritize tax reforms and domestic investments in education and infrastructure. At the supranational level, the NAFTA model should be upgraded to address its social lacunae, especially in the policy spheres of investment, immigration, agriculture, and resource transfers.

Este artículo presenta el balance socioeconómico del Acuerdo de Libre comercio de América del Norte (TLCAN) para México quince años después de su entrada en vigor. Mediante un análisis de la evolución de los flujos de capitales y del comercio, y de su impacto sobre el empleo y el nivel de los salarios en los sectores industriales y agrícolas, el autor revela los logros y los límites del modelo de integración del TLCAN. Concluye que aunque el TLCAN no puede ser la solución a todos los problemas socioeconómicos de México, lo que el acuerdo padece, a pesar de todo, es una "institucionalidad (social) deficiente" que puede consolidarse por medio de reformas nacionales y supranacionales. A nivel nacional, el gobierno mexicano tiene que replantearse su estrategia de 
crecimiento dependiente de las exportaciones y dar prioridad a la reforma fiscal y a las inversiones en el sector de la educación y las infraestructuras. A nivel supranacional, el modelo del TLCAN debería mejorarse con el fin de subsanar sus carencias sociales, particularmente en los sectores de la inversión, la inmigración, la agricultura y las transferencias de recursos.

INDEX

Keywords : NAFTA, regional integration, free trade, Mexico; development, employment Mots-clés : ALENA, intégration régionale, libre-échange, Mexique, développement, emploi Palabras claves : TLCAN, integración regional, libre comercio, México, desarrollo, empleo

\section{AUTEUR}

\section{JEAN-BAPTISTE VELUT}

Université Paris-Est Marne-la-Vallée 